\title{
Free Metallophosphines: Extremely Electron-Rich Phosphorus Superbases that are Electronically and Sterically Tunable
}

\author{
Rui Wei, Shaoying Ju, Liu Leo Liu* \\ [a] Dr. R. Wei; S. Ju; Prof. Dr. L. L. Liu \\ Department of Chemistry and Shenzhen Grubbs Institute, Southern University of Science and Technology, Shenzhen 518055, China \\ E-mail: liuleoliu@sustech.edu.cn \\ Supporting information for this article is given via a link at the end of the document.
}

\begin{abstract}
A variety of research fields ranging from catalysis to materials science benefit from readily accessible electron-rich ancillary ligands such as phosphines with diverse stereoelectronic properties. We report herein a facile and highly modular access to an intriguing class of free Au-substituted phosphines (AuPhos), namely $(\mathrm{LAu})_{n} \mathrm{PR}_{3-\mathrm{n}}(\mathrm{L}=$ singlet carbene ligand; $\mathrm{R}=\mathrm{H}$, aryl, alkyl, silyl) $(\mathrm{n}=1$ 3). The Tolman electronic parameter (TEP) values coupled with theoretical investigations showcase that Au-substitution can boost the electron-releasing ability of AuPhos, thus leading to an electronically and sterically tunable, extremely electron-rich phosphorus center. The high basicity of AuPhos is attributed to the $d-p$ lone pair m-repulsion arising from interaction between electron-rich $\mathrm{d}^{10} \mathrm{Au}$ substituents and the lone pair at $\mathrm{P}$. A series of multi-nuclear transition metal complexes (i.e. $\mathrm{Rh}, \mathrm{Ir}, \mathrm{Au}, \mathrm{W}, \mathrm{Mn}$ ) ligated by AuPhos are readily prepared via a straightforward process. Preliminary catalytic results reveal the facilitation of Ir-catalyzed decarbonylation reactions of aldehydes via AuPhos, unveiling their tremendous potential for the development and improvement of transition metal catalysts when electron-rich metal centers are required.
\end{abstract}

\section{Introduction}

The capability of ancillary ligands to tune the reactivity, selectivity, and stability of transition metal (TM) catalysts has generated many breakthroughs in homogeneous catalysis. ${ }^{[1]}$ Phosphines $\left(\mathrm{PR}_{3}\right)$ are one of the most versatile ligands, which are in large part the result of the sensitivity of the electron density and steric environments at the trivalent phosphorus center towards substituent modifications. ${ }^{[2]}$ Such elaboration of ligand architectures in a predictable manner plays a key role in providing optimum steric protection and stereoelectronic control of the active species. ${ }^{[2-3]}$ In addition, many other research fields such as organocatalysis ${ }^{[4]}$ frustrated Lewis pairs (FLPs), ${ }^{[5]}$ and nanomaterials ${ }^{[6]}$ have benefited from readily accessible phosphines having a broad range of steric effects and electronic properties.

While a large variety of phosphines have been documented, expanding the boundary of electron-releasing properties of phosphines remains quite challenging. ${ }^{[7]}$ The incorporation of $\pi$ donor substituents at $P$ has been shown to effectively increase such properties via $p$-p lone pair m-repulsion (Figure 1a). ${ }^{[8]}$ It has been demonstrated by Moloy and Petersen that, despite the electron-withdrawing inductive effect of the amino substituents, the potent $\mathrm{N}$-to-P $\mathrm{T}$-repulsion leads to comparable electrondonating ability of tris( $\mathrm{N}$-pyrrolidinyl)phosphines $\mathbf{A}$ and tris $(\mathrm{n}$ - butyl)phosphine. ${ }^{[9]}$ Proazaphosphatranes B described by Verkade et al. are early representatives of rare examples of strong donor phosphines. ${ }^{[10]}$ In 2017, the Dielmann group described the isolation of imidazolin-2-ylidenaminophosphines (IAPs) C with high basicity, ${ }^{[11]}$ and more recently they reported a tris(tetramethylguanidinyl)phosphine. ${ }^{[12]}$ In 2018, Gessner et al. disclosed a series of ylide-functionalized phosphines (YPhos) $\mathbf{D}^{[13]}$ and their superior performance in TM catalysis. ${ }^{[13 a, 14]}$ In 2019, Sundermeyer and co-workers showcased a fascinating class of electron-rich phosphazenyl phosphines (PAPs), ${ }^{[15]}$ one of which (E) represents the most electron-rich uncharged phosphorus Brønsted and Lewis base to date. However, the thermodynamically favored conformation of A-E adopts a perpendicular arrangement of adjacent lone pairs via rotation of $\mathrm{P}-\mathrm{E}(\mathrm{E}=\mathrm{N}$ or $\mathrm{C}$ ) single bonds (Figure $1 \mathrm{a}),{ }^{[9-13,15]}$ and this so called "gauche effect" ${ }^{16]}$ to some extent impedes boosting the phosphorus basicity.

Of note, the $d-p$ m-interaction has been demonstrated in terminal transition metal phosphide complexes. ${ }^{[17]}$ For example, the solidstate structure of a complex $\left[\mathrm{Ru}\left(\mathrm{PCy}_{2}\right)\left(\eta^{5}\right.\right.$-indenyl $\left.)\left(\mathrm{PPh}_{3}\right)\right]$ displays the $\mathrm{Ru}-\mathrm{PCy}_{2}$ bond length of $2.1589 \AA$ with considerable $\mathrm{Ru}-\mathrm{P} \pi$-bonding, which is $0.113 \AA$ shorter than that of $\mathrm{Ru}-\mathrm{PPh}_{3}$ bond $(2.2719 \AA) .{ }^{[18]}$ By contrast, the electronic repulsion of the P lone pair and nonbonding electrons at $\mathrm{Ru}$ in $(\mathrm{dmpe})_{2} \mathrm{Ru}(\mathrm{H})-\mathrm{P}(\mathrm{Me}) \mathrm{Ph} \quad$ (dmpe $\quad 1,2-$ bis(dimethylphosphino)ethane) leads to a much longer $\mathrm{Ru}-\mathrm{P}(\mathrm{Me}) \mathrm{Ph}$ bond length $(2.513 \AA)$ relative to that seen in $\left[(\mathrm{dmpe})_{2} \mathrm{Ru}(\mathrm{H})-(\mathrm{PHMePh})\right]\left[\mathrm{BPh}_{4}\right](2.342 \AA) .{ }^{[19]}$ The Bergman group showed high basicity of late TM amido complexes. ${ }^{[20]}$ In addition, transition-metal-substituted heavy tetrylenes have been documented by the Power, Tilley and Kato groups. ${ }^{[21]}$ We thus envisioned that incorporation of extremely electron-rich $d^{10} \mathrm{TM}$ substituents at phosphorus would give rise to a repulsive fourelectron destabilization that boosts the ground-state energy and makes the $P$ lone pair particularly basic. ${ }^{[17]}$ This gives access to highly electron-rich phosphines. Such $d-p$ m-repulsion is analogous to the abovementioned $p-p$ m-repulsion (Figures 1a and 1c). $\left.{ }^{[9-11}, 13 a, 15\right]$ Nonetheless, in this case rotation of the single bonds at $\mathrm{P}$ has less perturbation of $\mathrm{P}$-centered basicity due to the presence of five $d$-type nonbonding lone pairs at a $d^{10} \mathrm{TM}$ center with different orientations.

On the other hand, the isolobal analogy of the [LAu ${ }^{+}$cation and the proton $[\mathrm{H}]^{+}$has been well-established. ${ }^{[22]} \mathrm{As}[\mathrm{LAu}]^{+}$features a $5 d^{10}$ valence electron configuration and the ligand $L$ is highly modular, $(\mathrm{LAu})_{n} \mathrm{PR}_{3-\mathrm{n}}(\mathrm{n}=1-3)$ would be potentially phosphorus superbases and can be regarded as electronically and sterically tunable " $\mathrm{H}_{n} \mathrm{PR}_{3-n}$ " via variation of $\mathrm{L}$. While examination of the literature reveals a large number of bridging $\mathrm{Au}$ phosphine/phosphide complexes, ${ }^{[23]}$ there are only 
(a) Previous strategy

Extremely electron-rich via p-p $\pi$-repulsion

$E=$ main group element<smiles>[R]P1(F)(F)CCCCC1</smiles>

p-p $\pi$-repulsion

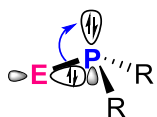

favored conformation (b)

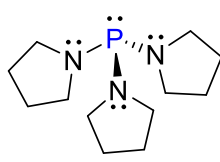

A<smiles>[R]C1N2CCN1P1N([R])CCN2CCN1[R]</smiles>

B

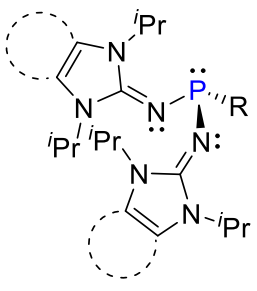

C

Moloy, Petersen

Dielmann

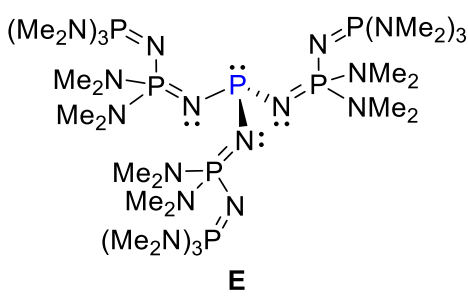

Sundermeyer<smiles></smiles>

$\mathrm{R}=\mathrm{R}^{\prime}=$ Mes, $\mathbf{F}$; Toste, Bergman $\mathrm{R}=\mathrm{Ph}, \mathrm{R}^{\prime}=\mathrm{SiMe}_{3}, \mathbf{G}$;

$\mathrm{R}=\mathrm{R}^{\prime}=\mathrm{SiMe}_{3}, \mathbf{H}$; Corrigan

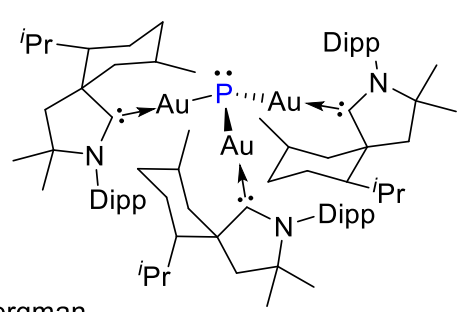

Bertrand, Grützmacher (c) This work

- Mono-, di-, and tri-TM-substituted terminal phosphines

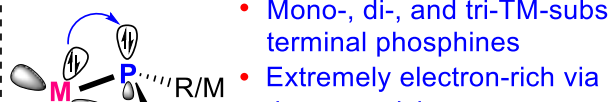

d-p $\pi$-repulsion

$\mathrm{R} / \mathrm{M}$
$\mathrm{d}-\mathrm{p} \pi$-repulsion

- Synthon for multi-nuclear TM complexes

- Catalysis

Figure 1. (a) Previous strategy. (b) Representative examples of highly electron-rich phosphines. (c) Present work.

two types of structurally characterized Au terminal phosphines disclosed by the groups of Toste, Bergman, Corrigan, Bertrand, and Grützmacher, namely mono-Au-substituted phosphine $\mathbf{F}_{\text {, }}{ }^{[2]}$ $\mathbf{G},{ }^{[25]} \mathbf{H},{ }^{[25]}$ and tri-Au-substituted phosphine ${ }^{[26]}$ (Figure 1a). F was synthesized via a deprotonation method, ${ }^{[24]}$ while $\mathbf{G}$ and $\mathbf{H}$ were derived from reactions involving the elimination of trimethylsilyl chloride. ${ }^{[25]}$ I was obtained serendipitously from a THF solution of an Au-PCO complex in low yield (i.e. $22 \%$ ). ${ }^{[26]}$ So far, their electronic properties and reactivities have been virtually unexplored. ${ }^{24-26]}$

In this contribution, we report that indeed Au-functionalization gives an intriguing family of highly electron-rich phosphines $(\mathrm{LAu})_{n} \mathrm{PR}_{3-\mathrm{n}}(\mathrm{L}=$ singlet carbene ligand; $\mathrm{R}=\mathrm{H}$, aryl, alkyl). These Au-substituted phosphines (AuPhos) are readily prepared via salt metathesis or desilylation reactions in high yields. The electronegative nature of gold $(X=2.54)$ makes the Au-P bonds in AuPhos highly covalent. The electronic and steric properties of AuPhos is easily tunable, which is crucial for broad applications in homogenous catalysis. This work expands the accessible stereoelectronic properties of phosphines beyond classical boundaries.

\section{Results and Discussion}

Design and Synthesis of Mono-AuPhos. To support our abovementioned hypothesis, density functional theory (DFT) investigations were carried out on model species $\mathrm{PH}_{3}$, (LAu) $\mathrm{PH}_{2}$,
$(\mathrm{LAu})_{2} \mathrm{PH}$ and $(\mathrm{LAu})_{3} \mathrm{P}(\mathrm{L}=1$,3-dimethylimidazol-2-ylidene) at the B3LYP-D3(BJ)/def2-SVP level of theory. Figure 2 clearly depicts the crucial roles of [LAu] substituents in increasing HOMO energies of the phosphorus lone pair. ${ }^{[27]}$ There are significant enhancements of the HOMO energies with respect to [LAu] substitution in the series $(\mathrm{LAu})_{n} \mathrm{PH}_{3-n}(\mathrm{n}=0-3)$. This is indicative of a cumulative $d-p$ m-repulsion effect from successive $d^{10}[L A u]$ groups.

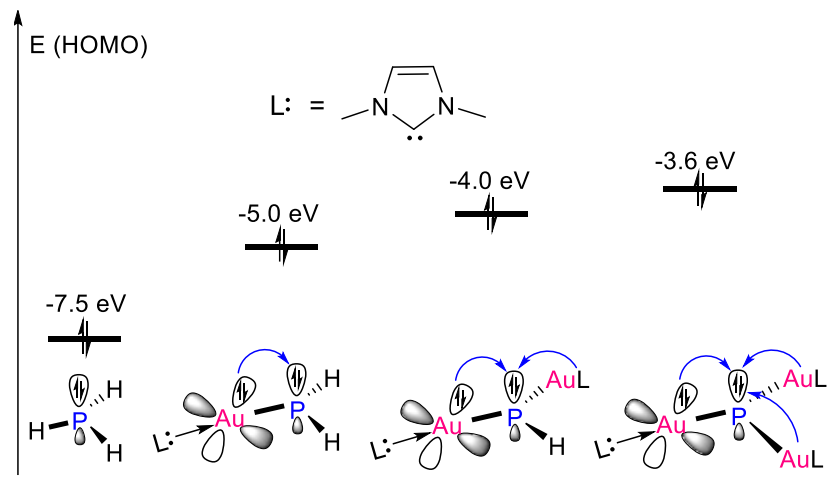

Figure 2. HOMO energies of $\mathrm{PH}_{3}$ and the model $(\mathrm{LAu})_{n} \mathrm{PH}_{3-\mathrm{n}}(\mathrm{n}=1,2,3)$.

Encouraged by these computational results, we first targeted the synthesis of mono-AuPhos ( $\mathrm{LAu}) \mathrm{PR}_{2}(\mathrm{~L}=$ diamidocarbene (DAC) 
(a)<smiles>CN1CN(C)C(=O)C(C)(C)C1=O</smiles>

$L^{1}$<smiles>CC1(C)CN(P(=O)(O)c2ccccc2)C(C)(C)C1</smiles>

$\mathrm{L}^{2}$<smiles></smiles>

$\mathbf{L}^{3}$<smiles>O=C1[Se]C(=[O+])C(=[Se])N1c1ccccc1</smiles>

$\mathrm{L}^{4}$

Increasing $\pi$-accepting ability

(b)

(c)

$$
L: \operatorname{AuCl} \frac{M P R^{1} R^{2}}{M=L i, N a, K} \quad L A u-\ddot{R}_{R^{1}}{ }^{\prime \prime \prime} R^{1}
$$

$\mathrm{L}=\mathrm{L}^{1}, \mathrm{R}^{1}=\mathrm{Ph} ; \mathbf{1}$ (observed) $\mathrm{L}=\mathrm{L}^{\mathbf{4}}, \mathrm{R}^{1}=\mathrm{Ph} ; \mathbf{4}$ (observed)

$\mathrm{L}=\mathrm{L}^{2}, \mathrm{R}^{1}=\mathrm{Ph} ; \mathbf{2}(54 \%) \quad \mathrm{L}=\mathrm{L}^{3}, \mathrm{R}^{1}=\mathrm{Ad} ; \mathbf{5}(86 \%)$

$\mathrm{L}=\mathrm{L}^{3}, \mathrm{R}^{1}=\mathrm{Ph} ; \mathbf{3}(90 \%) \quad \mathrm{L}=\mathrm{L}^{3}, \mathrm{R}^{1}=\mathrm{H} ; \mathbf{6}(91 \%)$ (d)

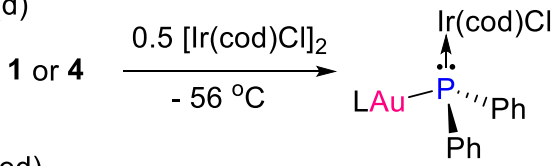

$\mathrm{L}=\mathrm{L}^{1} ; \mathbf{7}(51 \%)$

$\mathrm{L}=\mathrm{L}^{4} ; 8(67 \%)$

Figure 3. (a) $\pi$-Accepting ability of $\mathbf{L}^{1}-\mathbf{L}^{4}$. Mes $=$ mesityl; Dipp $=2,6$-diisopropylphenyl; $A r=2,6$-dimethylphenyl. (b) A graphical representation of modulation of $d$ $p$ m-repulsion via variation of L. (c) Synthesis of 1-6. (d) Trapping of $\mathbf{1}$ and $\mathbf{4}$.

$\mathbf{L}^{1}$, dimethyl cyclic (alkyl)(amino)carbene (MecAAC) $\mathbf{L}^{2}, \quad N$ heterocyclic carbene (NHC) $\mathbf{L}^{3}$, or bent allene $\mathbf{L}^{4} ; R=P h$, Ad, or $\mathrm{H}$ ) (Figures $3 a$ and $3 c$ ). ${ }^{[28]}$ It is well known that $L^{1}-L^{4}$ exhibit diverse $\pi$-acceptor properties (Figure 3a). ${ }^{[28-29]}$ We speculated the feasible modulation of the degree of Au/P d-p m-repulsion via variation of $L$ (Figure $3 b$ ). The more $\pi$-accepting ability of $L$ should result in the weaker $\pi$-repulsion (\& vice versa). This would provide access to electronically and sterically tunable AuPhos.

While a salt metathesis strategy was unsuccessful for the preparation of $\mathbf{F}$ (Figure 1b), ${ }^{[24]}$ treatment of $L A u C l\left(L=L^{2}\right.$ or $\left.L^{3}\right)$ with $\mathrm{KPPh}_{2}$ in DME or THF at room temperature afforded species $2\left({ }^{31}\right.$ P NMR: $\left.1.7 \mathrm{ppm}\right)$ or $3\left({ }^{31} \mathrm{P}\right.$ NMR: $\left.-1.0 \mathrm{ppm}\right)$ in 54 or $90 \%$ yield, respectively. The ${ }^{13} \mathrm{C}$ NMR spectra of 2 and 3 revealed diagnostic doublet resonances (2: 260.4 ppm; 3: 200.2 ppm) with the two-bond P-C couplings $(2: 37.5 \mathrm{~Hz} ; 3: 54.6 \mathrm{~Hz})$ attributable to the carbene carbons, indicating the formation of $\mathrm{Au}-\mathrm{P}$ bonds. The structures of $\mathbf{2}$ and $\mathbf{3}$ as mono-AuPhos were unambiguously determined by crystallographic studies (Figures $4 a$ and $4 b$ ). ${ }^{[30]}$ The $\mathrm{P}$ center of $\mathbf{2}$ and $\mathbf{3}$ adapts a trigonal-pyramidal geometry with the sum of angles equal to $307.7^{\circ}(2)$ and $315.2^{\circ}(3)$. Their lone pair of electrons point away from the Au center, imparting residual Lewis basicity at the $P$ donor. As expected, the stronger $\pi$ accepting ability of $L^{2}$ results in a shorter $A u(1)-C(1)$ bond length $(2.022(12) \AA)$ in 2 compared to that in $\mathbf{3}$ (2.062(5) $\AA$ ). The $\mathrm{Au}(1)-P(1)$ bond lengths are comparable (2: 2.314(3) $\AA$; 3 : $2.3193(13) \AA$ ). In a similar vein, dialkyl- and even dihydrogensubstituted analogs $5\left({ }^{31} \mathrm{P}\right.$ NMR: $\left.89.9 \mathrm{ppm}\right)$ and $6\left({ }^{31} \mathrm{P}\right.$ NMR: $250.3 \mathrm{ppm}$ ) were obtained via the reactions of $\mathrm{L}^{3} \mathrm{AuCl}$ with $\mathrm{LiPAd}_{2}$ $\left(\mathrm{Ad}=\right.$ adamantyl) and $\mathrm{NaPH}_{2}$ in high yields (> $\left.86 \%\right)$. In the solid state, the geometric parameters of $\mathbf{5}$ and $\mathbf{6}$ are comparable to those of 3 (Figures $4 c$ and $4 d$ ).
Although we were able to observe the formation of mono-AuPhos 1 ( ${ }^{31} \mathrm{P}$ NMR: $\left.52.4 \mathrm{ppm}\right)$ and $4\left({ }^{31} \mathrm{P}\right.$ NMR: $\left.9.6 \mathrm{ppm}\right)$ via in-situ ${ }^{31} \mathrm{P}$ NMR spectroscopic studies upon mixing $L A u C l\left(L=L^{1}\right.$ or $\left.L^{4}\right)$ with $\mathrm{KPPh}_{2}$ in THF at low temperature, such species were highly labile in solution (1: $\left.\mathrm{t}_{1 / 2}=0.5 \mathrm{~h} ; \mathbf{4}: \mathrm{t}_{1 / 2}=0.25 \mathrm{~h}\right)$, thus defying isolation. Nevertheless, chemical trapping experiments of $\mathbf{1}$ and $\mathbf{4}$ with $[\operatorname{Ir}(\operatorname{cod}) \mathrm{Cl}]_{2}$ at $-56^{\circ} \mathrm{C}$ allows the isolation of the ensuing iridium complexes 7 ( ${ }^{31} \mathrm{P}$ NMR: $\left.38.7 \mathrm{ppm}\right)$ and 8 ( ${ }^{31} \mathrm{P}$ NMR: $\left.31.4 \mathrm{ppm}\right)$ in 76 and $67 \%$ yields, respectively. Further structural authentication of 8 was established by X-ray diffraction (Figure 4e).

It is important to note that, in remarkable contrast to the sensitivity of metal phosphides with ionic M-P bonds, ${ }^{[31]}$ the high covalent character of the Au-P bonds in AuPhos (vide infra) makes these species highly stable towards alcohols, amines and even water. For example, $\mathbf{3}$ showed completely inertness with an equal molar portion of $\mathrm{EtOH},{ }^{i} \mathrm{PrOH},{ }^{t} \mathrm{BuOH}, \mathrm{Ph}_{2} \mathrm{NH},{ }^{\mathrm{P}} \mathrm{Pr}_{2} \mathrm{NH}$ and $\mathrm{H}_{2} \mathrm{O}$ (Figure S91-S98). The phosphine character of AuPhos was further demonstrated by the FLP reactivity of $5, \mathrm{BPh}_{3}$ and $\mathrm{H}_{2} \mathrm{O}$, which gave 9 and benzene. The former product was characterized by multi-nuclear NMR spectroscopy and X-ray diffraction (Figure 5).

Electronic Properties of Mono-AuPhos. Corresponding (AuPhos)Rh(acac)(CO) complexes were prepared by reactions of 1-5 with $\mathrm{Rh}(\mathrm{acac})(\mathrm{CO})_{2}$ (Figure 6). The electronic properties of these mono-AuPhos ligands were established by determination of the $\mathrm{CO}$ stretching frequency in these complexes in the solid state (Table 1). Complex 10 exhibits a distinctly higher frequency ( $v_{\mathrm{CO}}$ $\left.1943.4 \mathrm{~cm}^{-1}\right)$ with respect to those of $11\left(v_{\mathrm{co}} 1939.4 \mathrm{~cm}^{-1}\right), 12\left(v_{\mathrm{co}}\right.$ $\left.1938.7 \mathrm{~cm}^{-1}\right)$ and $13\left(\mathrm{v}_{\mathrm{CO}} 1935.8 \mathrm{~cm}^{-1}\right)$, indicative of reduced electron-releasing ability of $\mathbf{1}$ compared to $\mathbf{2 , 3}$ and $\mathbf{4}$. These data support the notion that decreasing the $\pi$-accepting ability of the $L$ 
(a)

(b)

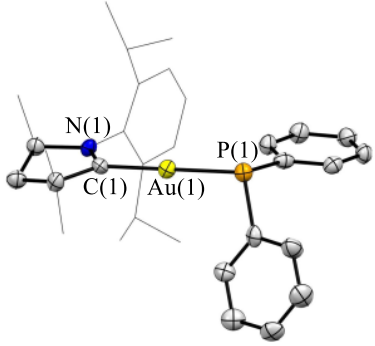

(c)

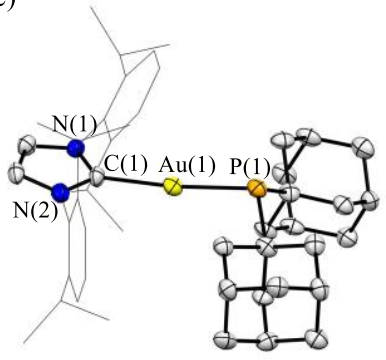

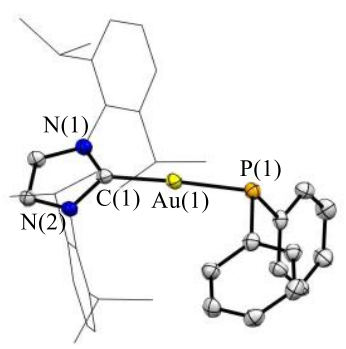

(d)

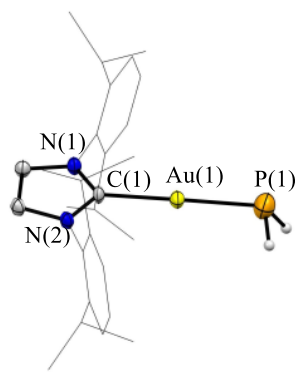

(e)

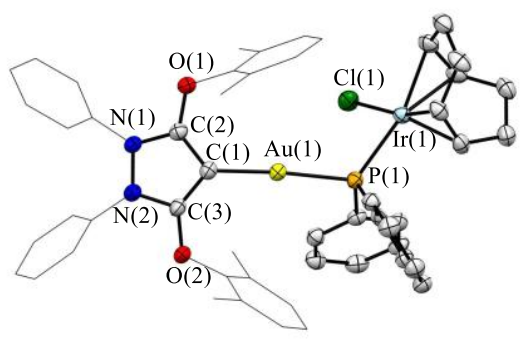

Figure 4. Solid-state structures of 2 (a), 3 (b), 5 (c), 6 (d) and 8 (e). Hydrogen atoms are omitted for clarity. Thermal ellipsoids are set at the $40 \%$ probability level.

leads to a decrease of the $\mathrm{v}_{\mathrm{CO}}$ frequency. Moreover, $\mathbf{5}$ is a stronger electron donor than $\mathbf{3}$ as demonstrated by the lower frequency of $\mathbf{1 4}\left(\mathrm{v}_{\mathrm{co}} 1934.9 \mathrm{~cm}^{-1}\right)$ compared to that of $\mathbf{1 2}\left(\mathrm{v}_{\mathrm{co}}\right.$ $\left.1938.7 \mathrm{~cm}^{-1}\right){ }^{[32]}$ The TEP values of $\mathbf{1 - 5}$ were subsequently calculated from the relationship between $\mathrm{v}_{\mathrm{CO}}$ for $(\mathrm{L}) \mathrm{Ni}(\mathrm{CO})_{3}$ and $(\mathrm{L}) \mathrm{Rh}(\mathrm{acac})(\mathrm{CO})$ complexes (Table 1). ${ }^{[7 a}$, 33$]$ Interestingly, monosubstitution of [LAu] shifts the TEP value $\left(\mathrm{PPh}_{3}: 2068.9 \mathrm{~cm}\right.$ $\left.{ }^{1}\right)^{[2]}$ by $19.6-24.4 \mathrm{~cm}^{-1}$. The TEP values of $1-5$ are $2049.3,2047.1$, 2046.7, 2045.0 and 2044.5, respectively. These are comparable to those of mono-imidazolin-2-ylidenamino-phosphines (2039$\left.2053 \mathrm{~cm}^{-1}\right),{ }^{[11]}$ whereas they are lower in comparison to those observed for YPhos D (2049-2067 $\left.\mathrm{cm}^{-1}\right)$ (Figure 1a). ${ }^{[13 a]}$ Notably, such TEP values of 1-5 support the conclusion that the donor character of mono-AuPhos is similar to that of the most classical NHCs. ${ }^{[34]}$ This also implies that di- and tri-substitution of [LAu] may surpass the donor abilities of singlet carbenes.

Theoretical Investigations. To gain more insight into the bonding and electron-rich nature of mono-AuPhos, DFT calculations, natural bond orbital (NBO) ${ }^{[35]}$ analyses, and energy decomposition analyses with natural orbitals for chemical valence (EDA-NOCV) ${ }^{[36,37]}$ calculations were performed. The calculated HOMO energies of 1-4 (1: -4.68 eV; 2: $-4.50 \mathrm{eV}$; 3: -4.44 eV; 4: $4.20 \mathrm{eV}$ ) suggest that the basicity increases in the order of 1-4. Additionally, electrostatic potential (ESP) calculations, which were demonstrated as a quantitative measure of the electronic effect of the phosphine ligands, ${ }^{[39]}$ show a linear correlation of the calculated value of the ESP at phosphorus of 1-5 $\left(\mathrm{V}_{P}\right)$ with their TEP values (Table 1 and Figure S85). Inspection of the NBOs of a selected model 3 clearly shows five nonbonding d-electron pairs

at $\mathrm{Au}$, a lone pair of electrons at $\mathrm{P}$, as well as an $\mathrm{Au}-\mathrm{P} \sigma$-bond (Figure 6).

(a)

5

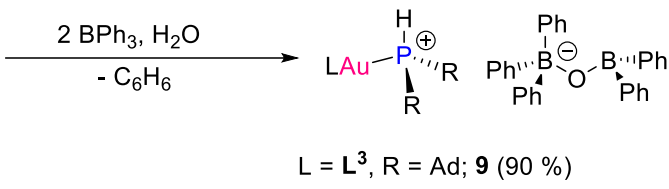

(b)

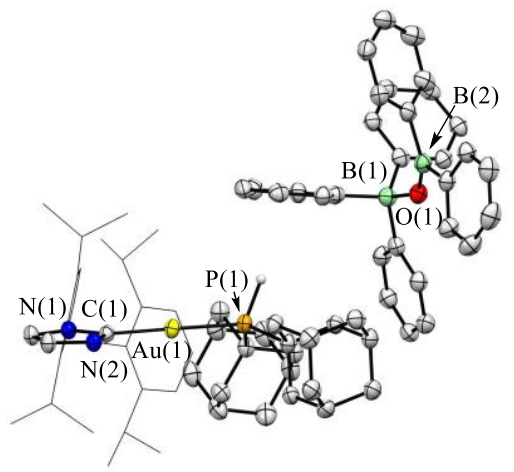

Figure 5. (a) Synthesis and solid-state structure of $\mathbf{9}$. Hydrogen atoms are omitted for clarity. Thermal ellipsoids are set at the $40 \%$ probability level.

(a)

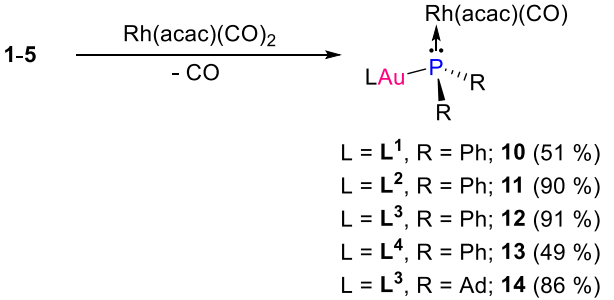

(b)

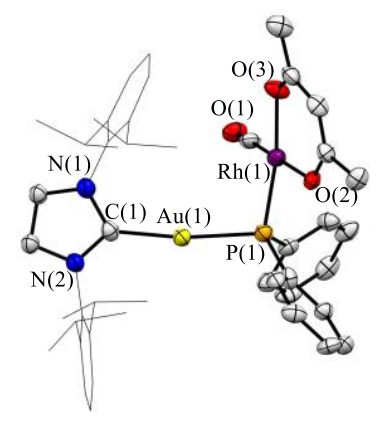

(c)

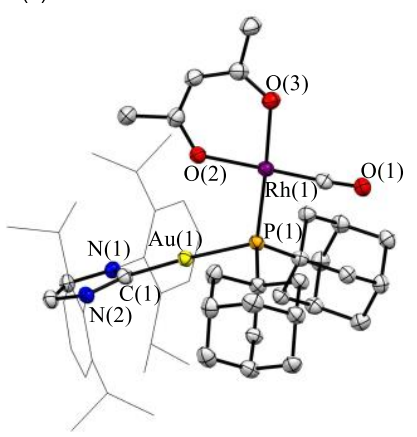

Figure 6. (a) Synthesis of 10-14. Solid-state structures of 12 (b) and 14 (c) Hydrogen atoms are omitted for clarity. Thermal ellipsoids are set at the $40 \%$ probability level.

As Pauli repulsion energies obtained from EDA-NOCV calculations can account for the unfavorable interaction of overlapping filled orbitals between fragments, we employed such energies to estimate the $d-p$ m-repulsion. ${ }^{[36]}$ We found that the $\pi$ accepting ability of $L$ can considerably effect the Pauli repulsion energy between [LAu•] and [•PPh $]$ fragments in 1-4. Such energies of $\mathbf{1}, \mathbf{2}, \mathbf{3}$ and $\mathbf{4}$ are calculated to be 191.2, 212.3, 218.4 and $221.1 \mathrm{kcal} / \mathrm{mol}$, respectively (Figures S86-S89), in line with 


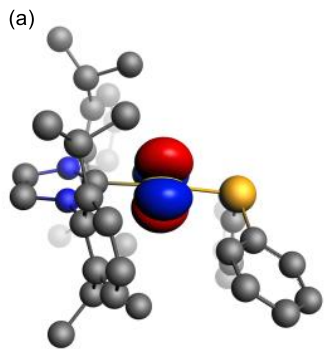

(e)

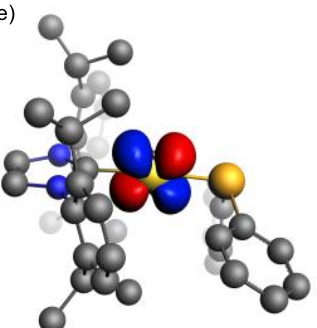

(b)

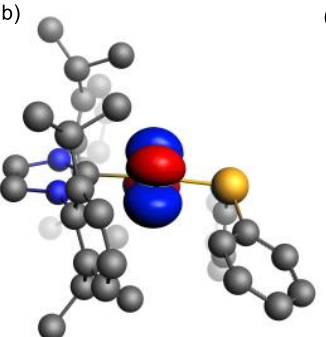

(f)

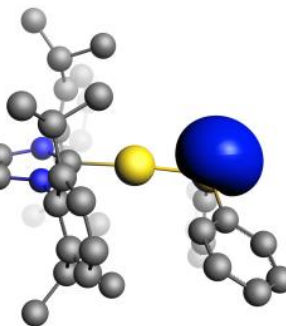

(c)

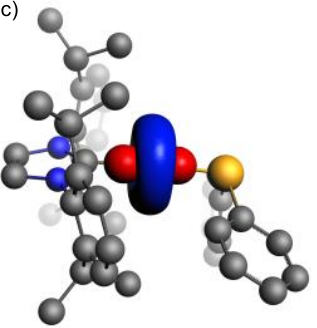

(g)

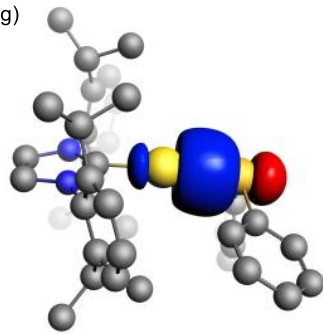

(d)

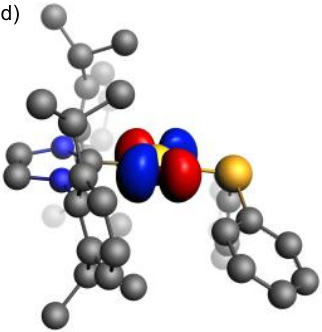

Figure 7. Selected NBOs of 3. Lone pair = LP. (a) Au LP (dxz-yz). (b) Au LP (dxy). (c) Au LP (dzz). (d) Au LP (dyz). (e) Au LP (dxz). (f) P LP. (g) Au-P $\sigma-b o n d$.

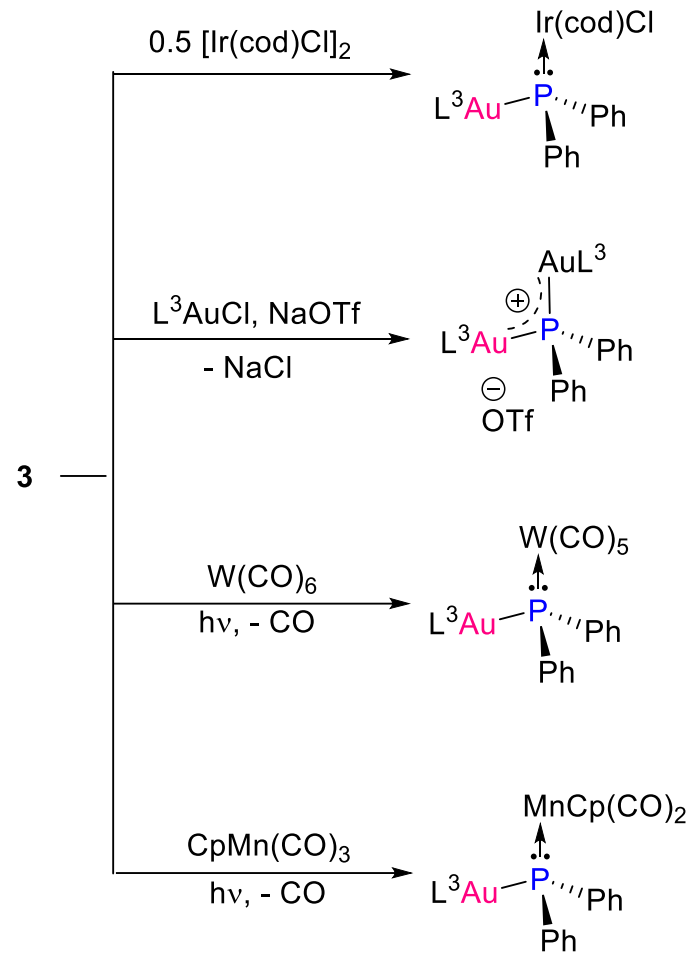

$15(87 \%)$

$17(90 \%)$

$18(80 \%)$

Figure 8. Synthesis of 15-18.

the trend of the observed TEP values. Taken as a whole, the Ausubstitution is proven to enhance the electron-releasing character of AuPhos via $d-p$ m-repulsion. Variation of the $L$ readily modulates the strength of the repulsion.

The quantum theory of atoms in molecules (QTAIM) ${ }^{[40]}$ analysis of 3 reveals that the electron density $\rho(r)$ at the bond critical point (BCP) of $\mathrm{Au}-\mathrm{P}$ bond is 0.10 a.u., while the energy density $\mathrm{H}(\mathrm{r})$ is -0.04 a.u., which indicate the covalent character of the P-Au bond. This is consistent with the localized orbital locator (LOL) ${ }^{[41]}$ analysis that demonstrates the region between the $\mathrm{P}$ and $\mathrm{Au}$ atoms with concentrated kinetic energy density, similar to those observed for the P-C and Au-C bonds(Figure S90).

With AuPhos available, we made attempts to experimentally measure their $p \mathrm{~K}_{\mathrm{BH}+}$ via NMR titration. ${ }^{[42]}$ The conjugate acid $\left[{ }^{3} \mathrm{AuPHPh}_{2}\right]\left[\mathrm{BF}_{4}\right]$ of $\mathbf{3}$ was prepared by treating $\mathrm{L}^{3} \mathrm{AuCl}$ with $\mathrm{HPPh}_{2} / \mathrm{AgBF}_{4}$. However, this method was problematic: the combination of 3 and $\left[\mathrm{L}^{3} \mathrm{AuPHPh} \mathrm{PH}_{2}\right]\left[\mathrm{BF}_{4}\right]$ led to an instantaneous demetallation reaction, yielding $\left[\left(\mathrm{L}^{3} \mathrm{Au}\right)_{2} \mathrm{PPh}_{2}\right]\left[\mathrm{BF}_{4}\right](23.8 \mathrm{ppm})$, $\mathrm{HPPh}_{2}(-40.5 \mathrm{ppm})$ and $\mathrm{L}^{3} \mathrm{AuPPh}_{2}(-1.0 \mathrm{ppm})$. Nevertheless, DFT calculations, which were shown in satisfying agreement with the

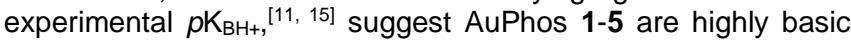
with the $p \mathrm{~K}_{\mathrm{BH}+}$ having values of 25.5, 29.3, 29.1, 35.6 and 38.3, respectively (Table 1). For comparison, the calculated $\mathrm{pK}_{\mathrm{BH}+}$ values of $\mathrm{P}^{t} \mathrm{Bu}_{3}$ (16.1) are consistent with the experimental observations (17.0). (a)

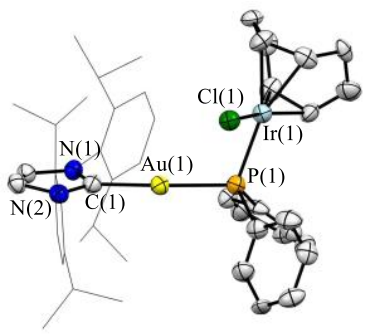

(c)

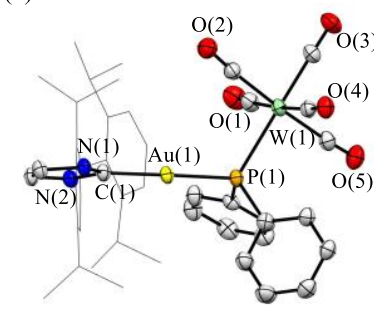

(b)

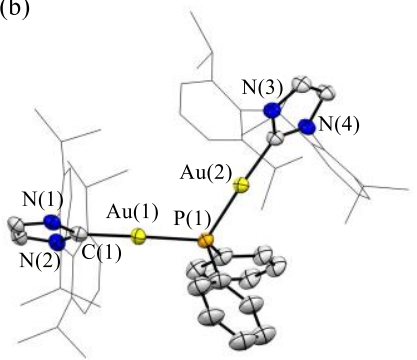

(d)

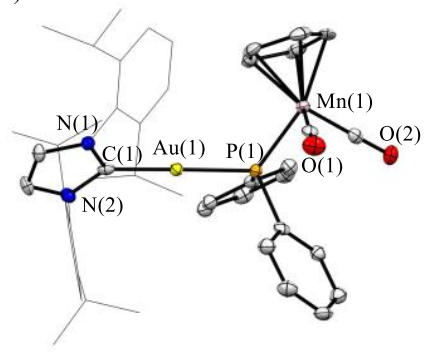

Figure 9. Solid-state structures of 15 (a), 16 (b), 17 (c) and 18 (d). Hydrogen atoms and the OTf anion are omitted for clarity. Thermal ellipsoids are set at the $40 \%$ probability level. 
(a)

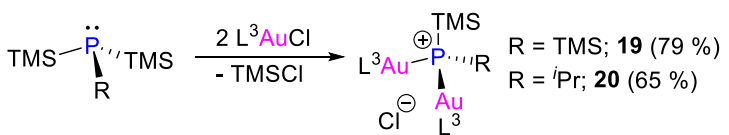

$$
\begin{aligned}
& { }^{t} \mathrm{BuOK} \mid-{ }^{t} \mathrm{BuOTMS} \\
& -56{ }^{\circ} \mathrm{C}-\mathrm{KCl}
\end{aligned}
$$

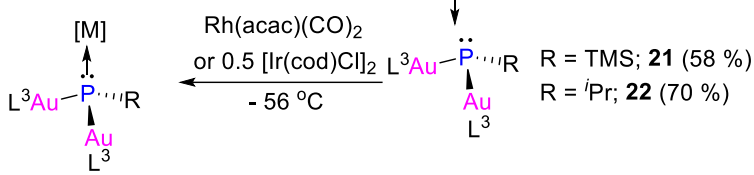

$$
\begin{aligned}
& \mathrm{R}={ }^{i} \mathrm{Pr} ;[\mathrm{M}]=\mathrm{Rh}(\mathrm{acac})(\mathrm{CO}) ; 23(57 \%) \\
& \mathrm{R}={ }^{i} \mathrm{Pr} ;[\mathrm{M}]=\mathrm{Ir}(\mathrm{cod}) \mathrm{Cl} ; 24(61 \%)
\end{aligned}
$$

(b)

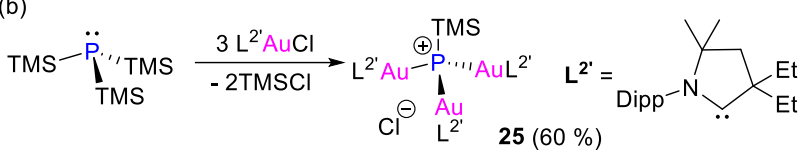

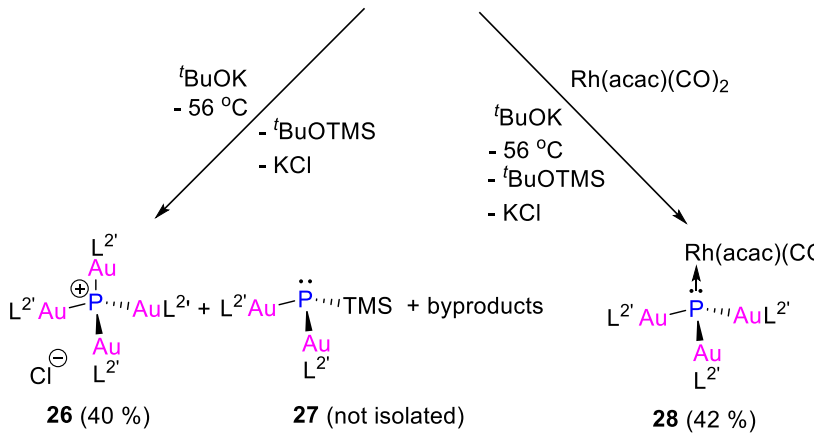

Figure 10. (a) Synthesis of di-AuPhos 20 and 21 and complex 22. (b) Generation and trapping of tri-AuPhos leading to 24-27.

The steric demand of the AuPhos ligand was estimated using the buried volume $\left(\% \mathrm{~V}_{\mathrm{bur}}\right)^{[43]}$ from the optimized geometries of the corresponding (AuPhos)AuCl complexes (Table 1). Depending on the steric bulk of $\mathrm{L}, \% \mathrm{~V}_{\text {bur }}$ varies from 27.1 to $43.7 \%$. The $\% \mathrm{~V}_{\text {bur }}$ of 5 is even larger than the value calculated for $\mathrm{PAd}_{3}(40.5 \%) .{ }^{[7 a]}$ Of critical importance, sterically encumbering ligands are beneficial for a large number of TM-catalyzed reactions, ${ }^{[44]}$ implying potentially high catalytic performance of AuPhos.

Coordination Chemistry of Mono-AuPhos. Dinuclear metal complexes have found numerous applications in catalysis. ${ }^{[45]}$ Indeed, these mono-AuPhos are powerful synthons for heteroand homo-dinuclear complexes (Figure 7 ). 3 readily reacted with $\left[\mathrm{Ir}(\mathrm{cod}) \mathrm{Cl}_{2}\right.$ or $\mathrm{L}^{3} \mathrm{AuCl} / \mathrm{NaOTf}$ at room temperature to give a neutral Au/Ir complex $15\left({ }^{31} \mathrm{P}\right.$ NMR: $\left.29.0 \mathrm{ppm}\right)$ or a cationic diauro complex 16 ( ${ }^{31} \mathrm{P}$ NMR: $23.8 \mathrm{ppm}$ ) in high yield (> $83 \%$ ), respectively. While 3 was completely inert with $\mathrm{W}(\mathrm{CO})_{6}$ without irradiation, upon exposing to UV lamp (254 nm) an Au/W complex $17\left({ }^{31} \mathrm{P}\right.$ NMR: $\left.-12.6 \mathrm{ppm}\right)$ was isolated in $90 \%$. Similarly, an Au/Mn complex 18 ( ${ }^{31} \mathrm{P}$ NMR: $\left.76.9 \mathrm{ppm}\right)$ was formed through the photo-induced reaction with $\mathrm{CpMn}(\mathrm{CO})_{3}$. The solid-state molecular structures of 15-18 were determined by X-ray diffractometry (Figure 9 ). The facile preparation of $15-18$ paves a new way to hetero-dinuclear Au phosphide complexes that are rare and otherwise tricky to prepare. ${ }^{[46]}$

Synthesis of Di- and Tri-AuPhos. Attempts on synthesis of diAuPhos were undertaken. We chose a desilylation route with the corresponding silylphosphonium salt as a precursor (Figure 10a). These species 19 and $\mathbf{2 0}$ were easily prepared via the reaction of
$\mathrm{RPTMS}_{2}(\mathrm{R}=\mathrm{TMS}, \mathrm{Pr})$ and $\mathrm{L}^{3} \mathrm{AuCl}$. Treatment of $\mathbf{1 9}$ or $\mathbf{2 0}$ with ${ }^{t} \mathrm{BuOK}$ in THF at $-56{ }^{\circ} \mathrm{C}$ immediately generated a yellow solution, in which after workup di-AuPhos 21 ( ${ }^{31} \mathrm{P}$ NMR: -203.3 ppm) or 22 $\left({ }^{31} \mathrm{P}\right.$ NMR: $\left.-11.5 \mathrm{ppm}\right)$ were isolated as yellow powders in 58 or $70 \%$ yield, respectively. While characterization of 21 by multinuclear NMR spectroscopic methods and high-resolution mass spectrometry was achieved, it slowly decomposed even at low temperature in solution (e.g. THF and benzene) within hours to give an unidentified complex mixture, precluding the formation of single crystals. On the other hand, slow evaporation of a concentrated $\mathrm{Et}_{2} \mathrm{O}$ solution of 22 at $-30^{\circ} \mathrm{C}$ produced $\mathrm{X}$-ray quality pale-yellow single crystals. Although the systematic disorder of 22 in the solid state does not allow for an accurate discussion of bond lengths and angles, the structure of a free di-AuPhos was unambiguously authenticated (Figure 11a). Notably, 21 and 22 are the first examples of a group 11 free dimetallaphosphine.

The calculated $p \mathrm{~K}_{\mathrm{BH}_{+}}$of 21 (41.8) and 22 (41.9) are much higher than those of mono-AuPhos 1-5 (25.5-38.3) (Table 1), indicating the di-Au-substitution increases the $\mathrm{pK}_{\mathrm{BH}}$ by several orders of magnitude. The calculated $V_{P}$ values of 21 (-44.7) and $22(-52.4)$ suggest their high donor ability. Additionally, flanking two bulky $\mathbf{L}^{3}$ ligands, 21 and 22 exhibit large $\% \mathrm{~V}_{\text {bur }}$ values (21: $41.0 \%$; 22: $48.5 \%)$.

Such di-AuPhos proved to be versatile synthons for tri-nuclear TM complexes. The combination of 22 with $\mathrm{Rh}(\mathrm{acac})(\mathrm{CO})_{2}$ or $[\operatorname{lr}(\mathrm{cod}) \mathrm{Cl}]_{2}$ in $\mathrm{THF}$ at $-56^{\circ} \mathrm{C}$ gave rise to the ensuing complex 23 or $\mathbf{2 4}$ in $57 \%$ or $61 \%$ yield, respectively. In the solid state of $\mathbf{2 3}$, the bond length of $P(1)-R h(1)$ lies within the range of the typical single bond (Figure 11b). The Au(1)-Rh(1) (3.6282(8) $\AA$ ) and $\mathrm{Au}(2)-\mathrm{Rh}(1)(3.8560(7) \AA)$ separations are much longer than the Pyykkö standard value for an Au-Rh single bond $(2.49 \AA) .{ }^{[47]}$

Remarkably, infrared spectroscopic investigations of 23 gave a considerably low CO stretching frequency of $1902.4 \mathrm{~cm}^{-1}$ and its TEP value is calculated to be $2025.9 \mathrm{~cm}^{-1}$ (Table 1), demonstrating the presence of an extremely electron-rich phosphorus center. Significant to note is that this TEP is lower than most of the known trivalent phosphines (i.e. A-D, Figure 1a $)^{[9-11,13]}$ whereas higher relative to those observed for a handful of examples of PAPs (e.g. E: $\left.2014.5 \mathrm{~cm}^{-1}\right)$. ${ }^{[15]}$ Unfortunately, efforts to prepare $L R h(a c a c)(C O)$ complex $(L=21)$ were unsuccessful, precluding the measure of its TEP value.

Table 1. The spectroscopic/structural properties and DFT results of the different phosphine ligands.

\begin{tabular}{|c|c|c|c|c|c|}
\hline & $\begin{array}{c}\text { TEP } \\
\left(\mathrm{cm}^{-1}\right)\end{array}$ & $\mathrm{V}^{[\mathrm{b}]}$ & $\mathrm{GB}^{[\mathrm{c}]}$ & $\mathrm{p} K_{\mathrm{BH}^{[}}{ }^{[\mathrm{d}]}$ & $\% \mathrm{~V}_{\text {bur }}{ }^{[\mathrm{f}]}$ \\
\hline $\mathrm{PPh}_{3}$ & $2068.9^{[2]}$ & -23.4 & 230.2 & $7.6^{[\mathrm{e}]}$ & 30.0 \\
\hline $\mathrm{P}\left({ }^{t} \mathrm{Bu}\right)_{3}$ & $2056.1^{[2]}$ & -27.9 & 240.7 & $\begin{array}{c}16.1 \\
(17.0)^{[\mathrm{e}]}\end{array}$ & 37.4 \\
\hline $\mathbf{1}$ & 2049.3 & -35.4 & 254.7 & 25.5 & 39.1 \\
\hline $\mathbf{2}$ & 2047.1 & -39.5 & 259.6 & 29.3 & 27.1 \\
\hline $\mathbf{3}$ & 2046.7 & -40.1 & 259.6 & 29.1 & 41.2 \\
\hline $\mathbf{4}$ & 2045.0 & -42.1 & 268.1 & 35.6 & 40.8 \\
\hline $\mathbf{5}$ & 2044.5 & -44.0 & 272.0 & 38.3 & 43.7 \\
\hline $\mathbf{2 1}$ & N.A. ${ }^{[\mathrm{a}]}$ & -44.7 & 276.9 & 41.8 & 41.0 \\
\hline $\mathbf{2 2}$ & 2025.9 & -52.4 & 276.8 & 41.9 & 48.5 \\
\hline$\left(\mathrm{L}^{2} \mathrm{Au}\right)_{3}$ & 2025.4 & -58.5 & 282.5 & 45.8 & 50.0 \\
$\mathrm{P}$ & & & & & \\
\hline
\end{tabular}

[a] Efforts to prepare $\mathrm{LRh}(\mathrm{acac})(\mathrm{CO})$ complex $(\mathrm{L}=\mathbf{2 1})$ were unsuccessful. [b] ESP calculations were conducted at the B3LYP-D3BJ/def2-SVP level of theory

[C] Gas phase basicity (GB) $(\mathrm{kcal} / \mathrm{mol})$ were calculated at the PW6B95D3BJ//TPSS-D3BJ/def2-TZVP level of theory. 
[d] $\mathrm{pKBH}+$ values were referenced to $\left[\mathrm{HPPh}_{3}\right]^{+}\left[\mathrm{pKa}\left(\mathrm{CH}_{3} \mathrm{CN}\right)=7.6\right]$ at the PW6B95-D3BJ//TPSS-D3BJ/def2-TZVP level of theory using SDD solvation model $\left(\mathrm{CH}_{3} \mathrm{CN}\right)$.

[e] Experimental value.

[f] Buried volume values were obtained from the optimized structures of (AuPhos)AuCl complexes at the B3LYP-D3BJ/def2-SVP level of theory.

We adopted a similar strategy to generate tri-AuPhos (Figure 10b) However, desilylation of a triaurosilylphosphonium salt 25 in THF at $-56{ }^{\circ} \mathrm{C}$ in $30 \mathrm{~min}$ produced species 26 ( ${ }^{31} \mathrm{P}$ NMR: $\left.-160.3 \mathrm{ppm}\right)$ and $27\left({ }^{31} \mathrm{P}\right.$ NMR: $\left.-215.3 \mathrm{ppm}\right)$ rather than the desired free triAuPhos $\left(\mathrm{L}^{2} \mathrm{Au}\right)_{3} \mathrm{P}$. Attempts to observe $\left(\mathrm{L}^{2} \mathrm{Au}\right)_{3} \mathrm{P}$ failed as the demetallation reaction occurred exceedingly fast. The formulation of 26 as $\left[\left(\mathrm{L}^{2} \mathrm{Au}\right)_{4} \mathrm{P}\right][\mathrm{Cl}]$ was further confirmed by single crystal $\mathrm{X}$ ray diffraction (Figure 11c). 26 represents the first example of a tetra-aurophosphonium salt albeit the structure features of $\left[\mathrm{P}\left(\mathrm{AuPH}_{3}\right)_{4}\right]^{+}$were thoroughly investigated by quantum chemical calculations. ${ }^{[48]}$ Unlike its arsenic analog $\left[(\mathrm{LAu})_{4} \mathrm{As}\right][\mathrm{Cl}]\left(\mathrm{L}=\mathrm{Ph}_{3} \mathrm{P}\right)$ featuring the geometry of a distorted square, ${ }^{[49]}$ the solid-state structure of $\mathbf{2 6}$ displays a distorted tetrahedron geometry. ${ }^{[48 a]}$ The presence of aurophilic attraction was evident as the shortest $\mathrm{Au}(1)-\mathrm{Au}(3)$ distance is 3.4445(9) $\AA .{ }^{[50]}$ The longest $\mathrm{Au}(1)-\mathrm{Au}(2)$ distance is 3.9990(6) $\AA$.

To establish the donor behavior of tri-AuPhos, low-temperature chemical trapping experiments in the presence of $\mathrm{Rh}(\mathrm{acac})(\mathrm{CO})_{2}$ were conducted (Figure 10b). Gratifyingly, the formation of the Rh complex 28 was shown by a doublet ${ }^{31} \mathrm{P}$ NMR resonance at $137.1 \mathrm{ppm}\left(\mathrm{J}_{\mathrm{P}-\mathrm{Rh}}=93.7 \mathrm{~Hz}\right)$. X-ray diffractometry further confirmed the connectivity of $\mathbf{2 8}$ (Figure 11d). The TEP value of $\left(\mathrm{L}^{2} \mathrm{Au}\right)_{3} \mathrm{P}\left(2025.4 \mathrm{~cm}^{-1}\right)$ is only slightly lower compared with that of $22\left(2025.9 \mathrm{~cm}^{-1}\right)$, which is likely due to the $\pi$-accepting nature of $\mathbf{L}^{2}$ over $\mathbf{L}^{3}$. It is important to note that the preparation of $\mathbf{2 5}$ is unique as the similar reaction of $\mathrm{PTMS}_{3}$ with $\mathrm{L}^{3} \mathrm{AuCl}$ in a molar ratio of $1: 3$ only gave 19 , along with unchanged $L^{3} \mathrm{AuCl}$. The lack of suitable synthetic routes towards [( $\left.\mathrm{LAu})_{3} \mathrm{PTMS}\right][\mathrm{Cl}]\left(\mathrm{L}=\mathrm{L}^{1}, \mathrm{~L}^{3}\right.$, $L^{4}$ ) limits the exploration of other tri-AuPhos. More efficient methods leading to free tri-AuPhos are therefore needed in the future study. (a)

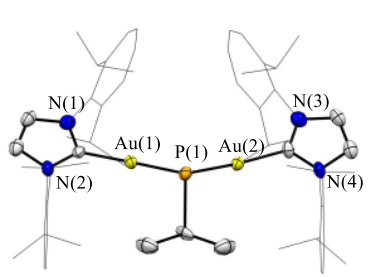

(c)

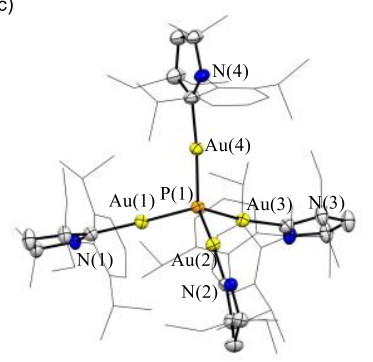

(b)
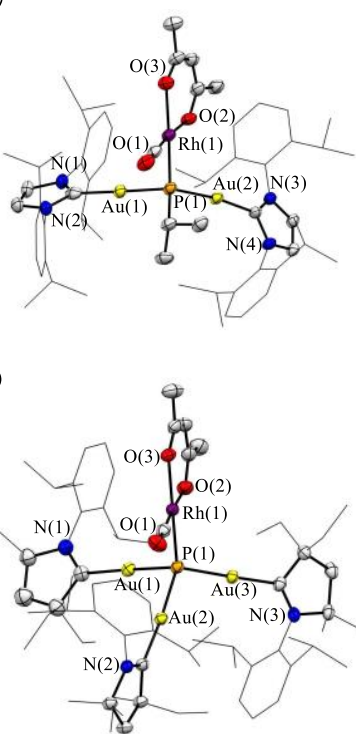

Figure 11. Solid-state structures of 22 (a), 23 (b), 26 (c), and 28 (d). Hydrogen atoms are omitted for clarity. Thermal ellipsoids are set at the $40 \%$ probability level.
Table 2. Ir-catalyzed decarbonylation reaction of 2naphthaldehyde. ${ }^{\text {a }}$

\begin{tabular}{|c|c|c|c|}
\hline Entry & Ligand & $\mathrm{T}[\mathrm{h}]$ & NMR Yield [\%] \\
\hline 1 & $\mathrm{no}$ & 12 & 0 \\
\hline 2 & $\mathrm{PPh}_{3}$ & 2 & 4 \\
\hline 3 & $\mathrm{PPh}_{3}$ & 12 & 14 \\
\hline 4 & $\mathrm{PCy}_{3}$ & 2 & 5 \\
\hline 5 & $\mathrm{PCy}_{3}$ & 12 & 17 \\
\hline 6 & $\mathrm{PCy}_{3}$ & 24 & 27 \\
\hline 7 & $\mathbf{3}$ & 2 & 24 \\
\hline 8 & $\mathbf{3}$ & 12 & 46 \\
\hline 9 & $\mathbf{5}$ & 2 & 48 \\
\hline 10 & $\mathbf{5}$ & 12 & 71 \\
\hline 11 & $\mathbf{5}$ & 24 & 85 \\
\hline 12 & $\mathbf{5}$ & 12 & 0 \\
\hline
\end{tabular}

[a] Conditions: 2-naphthaldehyde $(0.25 \mathrm{mmol}),[\operatorname{lr}(\operatorname{cod}) \mathrm{Cl}]_{2}(2 \mathrm{~mol} \%)$, ligand $(4$ $\mathrm{mol} \%)$, in a mixed solvent consisting of THF $(5 \mathrm{~mL})$ and $\mathrm{C}_{6} \mathrm{D}_{6}(1 \mathrm{~mL}), 75^{\circ} \mathrm{C}$, Ar.

[b] In the absence of $\left[\operatorname{Ir}(\operatorname{cod}) \mathrm{Cl}_{2}\right.$.

Catalysis. Numerous TM-catalyzed transformations that require electron-rich metal centers will benefit from the electron-donating phosphines. Among them, the use of electron-releasing phosphine ligands have been shown to facilitate Ir-catalyzed decarbonylation reactions of aldehydes. ${ }^{[51]}$ This prompted us to explore such catalytic reactions with our AuPhos (Table 2). The combination of commercially available $[\operatorname{Ir}(\mathrm{cod}) \mathrm{Cl}]_{2}(2 \mathrm{~mol} \%)$ and $\mathrm{PPh}_{3}$ or $\mathrm{PCy}_{3}(4 \mathrm{~mol} \%)$ only sluggishly promoted the decarbonylation of 2-naphthaldehyde in refluxing $T H F / C_{6} D_{6}(v: v=$ $5: 1$ ) (i.e. $75^{\circ} \mathrm{C}$ ) (Entries 2-6). Gratifyingly, employing AuPhos 3 or 5 provided much higher catalytic activity (Entries 7-11), giving the product naphthalene in yields of up to $85 \%$ within $24 \mathrm{~h}$ (Entry 11). In the absence of either $[\operatorname{Ir}(\operatorname{cod}) \mathrm{Cl}]_{2}$ or ligand, no conversion was observed (Entries 1 and 12). These results combined, demonstrates the remarkable potential of AuPhos in the development of TM catalysis.

\section{Conclusion}

To conclude, we have systematically explored a family of AuPhos, including mono-, di- and tri-AuPhos. These species are readily synthesized via either a salt metathesis reaction or a desilylation reaction. The electron-rich nature of AuPhos is attributed to the d$p$ lone pair repulsion, which can be easily modulated by modifying the $\pi$-accepting ability of the $L$ at Au. This makes AuPhos extremely electron-rich phosphorus superbases that are electronically and sterically tunable. Importantly, this concept could be extended to other systems with tunable electronic properties. AuPhos have also shown as potent synthons for multinuclear TM complexes. Preliminary attempts on catalysis reveal that AuPhos can improve the outcome of Ir-catalyzed decarbonylation reactions of aldehydes, showcasing their huge potential for the development and improvement of TM catalysis when electron-rich metal centers are required. The application of AuPhos in the production of other catalytically active species, the 
deeper evaluation of these new TM complexes, and the extension of AuPhos as catalysts are the subjects of ongoing work.

\section{Acknowledgements}

We gratefully acknowledge financial support from the National Natural Science Foundation of China (22101114) and SUSTech startup fund (Y01216248). We acknowledge the technical support from SUSTech Core Research Facilities. The theoretical work is supported by the Center for Computational Science and Engineering and CHEM High-Performance Supercomputer Cluster at SUSTech. We thank Dr. Xiaoyong Chang and Dr. Yuhui Hua at SUSTech for assistance in X-ray diffraction analyses. Prof. Qing Ye, Mr. Weicheng Sun and Dr. Chunyan Wang are thanked for assistance in FTIR experiments. Dr. David A. Ruiz is also thanked for valuable discussion and continuous support.

\section{Conflict of Interest}

The authors declare no conflict of interest.

Keywords: Phosphine; Metal substituents; Multi-nuclear complexes; Electron-rich; Catalysis

\section{References:}

[1] (a) O. M. Ogba, N. C. Warner, D. J. O'Leary, R. H. Grubbs Chem. Soc. Rev. 2018, 47, 4510-4544; (b) J. He, M. Wasa K. S. L. Chan, Q. Shao, J.-Q. Yu, Chem. Rev. 2017, 117, 8754-8786; (c) N. Miyaura, A. Suzuki, Chem. Rev. 1995, 95, 2457-2483; (d) M. N. Hopkinson, C. Richter, M. Schedler, F. Glorius, Nature 2014, 510, 485-496; (e) R. Jazzar, M. Soleilhavoup, G. Bertrand, Chem. Rev. 2020, 120, 41414168.

[2] C. A. Tolman, Chem. Rev. 1977, 77, 313-348

[3] (a) J.-H. Xie, S.-F. Zhu, Q.-L. Zhou, Chem. Rev. 2011, 111, 1713-1760; (b) D. J. Durand, N. Fey, Chem. Rev. 2019, 119 6561-6594; (c) Q. Yin, Y. Shi, J. Wang, X. Zhang, Chem. Soc. Rev. 2020, 49, 6141-6153; (d) P. C. J. Kamer, P. W. N. M. van Leeuwen, J. N. H. Reek, Acc. Chem. Res. 2001 , 34, 895-904; (e) R. Martin, S. L. Buchwald, Acc. Chem. Res. 2008, 41, 1461-1473; (f) D. S. Surry, S. L. Buchwald, Angew. Chem., Int. Ed. 2008, 47, 6338-6361.

[4] (a) H. Guo, Y. C. Fan, Z. Sun, Y. Wu, O. Kwon, Chem. Rev. 2018, 118, 10049-10293; (b) Y. Wei, M. Shi, Acc. Chem Res. 2010, 43, 1005-1018; (c) J. M. Lipshultz, G. Li, A. T. Radosevich, J. Am. Chem. Soc. 2021, 143, 1699-1721; (d) T. R. Puleo, S. J. Sujansky, S. E. Wright, J. S. Bandar, Chem. Eur. J. 2021, 27, 4216-4229.

[5] (a) A. R. Jupp, D. W. Stephan, Trends Chem. 2019, 1, 35 48; (b) D. W. Stephan, Science 2016, 354, aaf7229; (c) D. W. Stephan, G. Erker, Angew. Chem., Int. Ed. 2015, 54, 6400-6441.

[6] (a) S. Kim, Y. T. Lim, E. G. Soltesz, A. M. De Grand, J. Lee, A. Nakayama, J. A. Parker, T. Mihaljevic, R. G. Laurence, D. M. Dor, L. H. Cohn, M. G. Bawendi, J. V. Frangioni, Nat Biotechnol. 2004, 22, 93-97; (b) M. Walter, J. Akola, O. Lopez-Acevedo, P. D. Jadzinsky, G. Calero, C. J. Ackerson, R. L. Whetten, H. Grönbeck, H. Häkkinen, Proc. Natl. Acad. Sci. U. S. A. 2008, 105, 9157-9162.

[7] (a) L. Chen, P. Ren, B. P. Carrow, J. Am. Chem. Soc. 2016 138, 6392-6395; (b) J. F. Kögel, D. Margetić, X. Xie, L. H. Finger, J. Sundermeyer, Angew. Chem., Int. Ed. 2017, 56 , 3090-3093; (c) J. F. Kögel, B. Oelkers, B. Kovačević, J Sundermeyer, J. Am. Chem. Soc. 2013, 135, 17768-17774; (d) J. F. Kögel, N.-J. Kneusels, J. Sundermeyer, Chem Commun. 2014, 50, 4319-4321; (e) J. F. Kögel, B Kovačević, S. Ullich, X. Xie, J. Sundermeyer, Chem. Eur. J. 2017, 23, 2591-2598.

[8] (a) R. F. Weitkamp, B. Neumann, H.-G. Stammler, B. Hoge Chem. Eur. J. 2021, 27, 10807-10825; (b) A. Sarbajna, V. S. V. S. N. Swamy, V. H. Gessner, Chem. Sci. 2021, 12, 2016-2024.

[9] K. G. Moloy, J. L. Petersen, J. Am. Chem. Soc. 1995, 117 7696-7710.

[10] (a) P. B. Kisanga, J. G. Verkade, R. Schwesinger, J. Org Chem 2000, 65, 5431-5432; (b) C. Lensink, S. K. Xi, L. M. Daniels, J. G. Verkade, J. Am. Chem. Soc. 1989, 111 3478-3479.

[11] (a) M. A. Wünsche, P. Mehlmann, T. Witteler, F. Buß, P Rathmann, F. Dielmann, Angew. Chem., Int. Ed. 2015, 54, 11857-11860; (b) F. Buß, P. Mehlmann, C. MückLichtenfeld, K. Bergander, F. Dielmann, J. Am. Chem. Soc 2016, 138, 1840-1843; (c) P. Rotering, L. F. B. Wilm, J. A Werra, F. Dielmann, Chem. Eur. J. 2020, 26, 406-411; (d) P. Mehlmann, T. Witteler, L. F. B. Wilm, F. Dielmann, Nat. Chem. 2019, 11, 1139-1143.

F. Buß, M. B. Röthel, J. A. Werra, P. Rotering, L. F. B. Wilm, C. G. Daniliuc, P. Löwe, F. Dielmann, Chem. Eur. J. 2022 28, e202104021.

[13] (a) T. Scherpf, C. Schwarz, L. T. Scharf, J.-A. Zur, A. Helbig V. H. Gessner, Angew. Chem., Int. Ed. 2018, 57, 1285912864; (b) J. Löffler, R. M. Gauld, K.-S. Feichtner, I. Rodstein, J.-A. Zur, J. Handelmann, C. Schwarz, V. H. Gessner, Organometallics 2021, 40, 2888-2900.

(a) H. Darmandeh, J. Löffler, N. V. Tzouras, B. Dereli, T. Scherpf, K.-S. Feichtner, S. Vanden Broeck, K. Van Hecke M. Saab, C. S. J. Cazin, L. Cavallo, S. P. Nolan, V. H. Gessner, Angew. Chem., Int. Ed. 2021, 60, 21014-21024 (b) X.-Q. Hu, D. Lichte, I. Rodstein, P. Weber, A.-K. Seitz, T. Scherpf, V. H. Gessner, L. J. Gooßen, Org. Lett. 2019 , 21, 7558-7562; (c) P. Weber, T. Scherpf, I. Rodstein, D. Lichte, L. T. Scharf, L. J. Gooßen, V. H. Gessner, Angew Chem., Int. Ed. 2019, 58, 3203-3207; (d) J. Tappen, I. Rodstein, K. McGuire, A. Großjohann, J. Löffler, T. Scherpf, V. H. Gessner, Chem. Eur. J. 2020, 26, 4281-4288; (e) T. Scherpf, H. Steinert, A. Großjohann, K. Dilchert, J. Tappen, I. Rodstein, V. H. Gessner, Angew. Chem., Int. Ed. 2020 59, 20596-20603; (f) L. T. Scharf, I. Rodstein, M. Schmidt, T. Scherpf, V. H. Gessner, ACS Cat. 2020, 10, 999-1009; (g) Z. Hu, X.-J. Wei, J. Handelmann, A.-K. Seitz, I. Rodstein, V. H. Gessner, L. J. Gooßen, Angew. Chem., Int. Ed. 2021, 60, 6778-6783; (h) J. Handelmann, C. N. Babu, H. Steinert, C. Schwarz, T. Scherpf, A. Kroll, V. H. Gessner, Chem. Sci. 2021, 12, 4329-4337; (i) S. Lapointe, A. Sarbajna, V. H. Gessner, Acc. Chem. Res. 2022, 55, 770-782.

[15] S. Ullrich, B. Kovačević, X. Xie, J. Sundermeyer, Angew. Chem., Int. Ed. 2019, 58, 10335-10339.

[16] (a) S. Wolfe, Acc. Chem. Res. 1972, 5, 102-111; (b) L. Radom, W. J. Hehre, J. A. Pople, J. Am. Chem. Soc. 1972 94, 2371-2381; (c) A. H. Cowley, D. J. Mitchell, M.-H. Whangbo, S. Wolfe, J. Am. Chem. Soc. 1979, 101, 52245231.

[17] (a) G. T. Crisp, G. Salem, S. B. Wild, F. S. Stephens Organometallics 1989, 8, 2360-2367; (b) D. S. Bohle, G. R. Clark, C. E. F. Rickard, W. R. Roper, J. Organomet. Chem. 1990, 393, 243-285; (c) D. S. Glueck, Dalton Trans. 2008, 5276-5286; (d) R. Waterman, Dalton Trans. 2009, 18-26; (e) V. S. Chan, M. Chiu, R. G. Bergman, F. D. Toste, J. Am Chem. Soc. 2009, 131, 6021-6032.

[18] E. J. Derrah, D. A. Pantazis, R. McDonald, L. Rosenberg, Organometallics 2007, 26, 1473-1482.

[19] V. S. Chan, I. C. Stewart, R. G. Bergman, F. D. Toste, J. Am. Chem. Soc. 2006, 128, 2786-2787.

[20] (a) A. W. Kaplan, J. C. M. Ritter, R. G. Bergman, J. Am. Chem. Soc. 1998, 120, 6828-6829; (b) J. R. Fulton, M. W. Bouwkamp, R. G. Bergman, J. Am. Chem. Soc. 2000, 122, 8799-8800; (c) J. R. Fulton, A. W. Holland, D. J. Fox, R. G. Bergman, Acc. Chem. Res. 2002, 35, 44-56; (d) J. R. Fulton, 
S. Sklenak, M. W. Bouwkamp, R. G. Bergman, J. Am. Chem. Soc. 2002, 124, 4722-4737.

[21] (a) L. Pu, B. Twamley, S. T. Haubrich, M. M. Olmstead, B. V. Mork, R. S. Simons, P. P. Power, J. Am. Chem. Soc. 2000, 122, 650-656; (b) A. C. Phung, J. C. Fettinger, P. P. Power, Organometallics 2021, 40, 3472-3479; (c) B. E. Eichler, A. D. Phillips, S. T. Haubrich, B. V. Mork, P. P. Power, Organometallics 2002, 21, 5622-5627; (d) P. G. Hayes, C. W. Gribble, R. Waterman, T. D. Tilley, J. Am. Chem. Soc. 2009, 131, 4606-4607; (e) H.-J. Liu, J. Guihaumé, T. Davin, C. Raynaud, O. Eisenstein, T. D. Tilley, J. Am. Chem. Soc. 2014, 136, 13991-13994; (f) L. Pu, P. P. Power, I. Boltes, R. Herbst-Irmer, Organometallics 2000, 19, 352-356; (g) P. W. Smith, R. C. Handford, T. D. Tilley, Organometallics 2019, 38, 4060-4065; (h) S. Takahashi, E. Bellan, A. Baceiredo, N. Saffon-Merceron, S. Massou, N. Nakata, D. Hashizume, V. Branchadell, T. Kato, Angew. Chem., Int. Ed. 2019, 58, 10310-10314.

[22] H. G. Raubenheimer, H. Schmidbaur, Organometallics 2012, 31, 2507-2522.

[23] (a) E. J. Fernandez, A. Taguna, M. E. Olmos, J. Chil. Chem. Soc. 2007, 52, 1200-1205; (b) D. M. Stefanescu, H. F. Yuen, D. S. Glueck, J. A. Golen, A. L. Rheingold, Angew. Chem., Int. Ed. 2003, 42, 1046-1048.

[24] M. W. Johnson, S. L. Shevick, F. D. Toste, R. G. Bergman, Chem. Sci. 2013, 4, 1023-1027.

[25] B. K. Najafabadi, J. F. Corrigan, Can. J. Chem. 2016, 94, 593-598.

[26] L. L. Liu, D. A. Ruiz, F. Dahcheh, G. Bertrand, R. Suter, A M. Tondreau, H. Grützmacher, Chem. Sci. 2016, 7, 23352341.

(a) K. G. Caulton, New J. Chem. 1994, 18, 25-41; (b) J. M. Mayer, Comments Inorg. Chem. 1988, 8, 125-135.

(a) O. Back, M. Henry-Ellinger, C. D. Martin, D. Martin, G Bertrand, Angew. Chem., Int. Ed. 2013, 52, 2939-2943; (b) V. Lavallo, C. A. Dyker, B. Donnadieu, G. Bertrand, Angew. Chem., Int. Ed. 2008, 47, 5411-5414.

(a) I. Fernández, C. A. Dyker, A. DeHope, B. Donnadieu, G. Frenking, G. Bertrand, J. Am. Chem. Soc. 2009, 131, 11875-11881; (b) A. Liske, K. Verlinden, H. Buhl, K Schaper, C. Ganter, Organometallics 2013, 32, 5269-5272. Deposition Numbers 2143958-2143973 and 2155838 contain the supplementary crystallographic data for this paper. These can be obtained free of charge via www.ccdc.cam.ac.uk/data request/cif.

(a) M. M. Rauhut, A. M. Semsel, J. Org. Chem 1963, 28 471-473; (b) A. Steiner, D. Stalke, Organometallics 1995, 14, 2422-2429; (c) T. Li, S. Kaercher, P. W. Roesky, Chem. Soc. Rev. 2014, 43, 42-57; (d) M. M. D. Roy, A. Heilmann, M. A. Ellwanger, S. Aldridge, Angew. Chem., Int. Ed. 2021, 60, 26550-26554.

[32] S. T. Howard, J. P. Foreman, P. G. Edwards, Inorg. Chem. 1996, 35, 5805-5812.

[33] S. Serron, J. Huang, S. P. Nolan, Organometallics 1998, 17 534-539.

[34] (a) T. Dröge, F. Glorius, Angew. Chem., Int. Ed. 2010, 49 6940-6952; (b) D. J. Nelson, S. P. Nolan, Chem. Soc. Rev. 2013, 42, 6723-6753.

[35] F. Weinhold, C. R. Landis, E. D. Glendening, Int. Rev. Phys. Chem. 2016, 35, 399-440.

[36] (a) A. Michalak, M. Mitoraj, T. Ziegler, J. Phy. Chem. A 2008 112, 1933-1939; (b) M. Mitoraj, A. Michalak, J. Mol. Model. 2008, 14, 681-687; (c) M. P. Mitoraj, A. Michalak, T. Ziegler, J. Chem. Theory Comput. 2009, 5, 962-975; (d) K Morokuma, Acc. Chem. Res. 1977, 10, 294-300; (e) T. Ziegler, A. Rauk, Theor. Chim. Acta 1977, 46, 1-10.

[37] (a) L. Zhao, S. Pan, N. Holzmann, P. Schwerdtfeger, G. Frenking, Chem. Rev. 2019, 119, 8781-8845; (b) L. Zhao, M. Hermann, N. Holzmann, G. Frenking, Coord. Chem. Rev. 2017, 344, 163-204; (c) L. Zhao, M. Hermann, W. H. E. Schwarz, G. Frenking, Nat. Rev. Chem. 2019, 3, 48-63.

[38] (a) L.-G. Zhuo, W. Liao, Z.-X. Yu, Asian J. Org. Chem. 2012 1, 336-345; (b) B. Rao, H. Tang, X. Zeng, L. L. Liu, M. Melaimi, G. Bertrand, Angew. Chem., Int. Ed. 2015, 54 14915-14919.
[39] C. H. Suresh, N. Koga, Inorg. Chem. 2002, 41, 1573-1578.

[40] (a) R. F. W. Bader, Chem. Rev. 1991, 91, 893-928; (b) R F. W. Bader, Monatsh. Chem. 2005, 136, 819-854.

[41] (a) H. L. Schmider, A. D. Becke, Journal of Molecular Structure: THEOCHEM 2000, 527, 51-61; (b) H. Jacobsen, Can. J. Chem. 2008, 86, 695-702.

[42] F. Vermersch, S. Yazdani, G. P. Junor, D. B. Grotjahn, R Jazzar, G. Bertrand, Angew. Chem., Int. Ed. 2021, 60, 27253-27257.

[43] L. Falivene, Z. Cao, A. Petta, L. Serra, A. Poater, R. Oliva V. Scarano, L. Cavallo, Nat. Chem. 2019, 11, 872-879.

[44] (a) S. H. Newman-Stonebraker, S. R. Smith, J. E. Borowski, E. Peters, T. Gensch, H. C. Johnson, M. S. Sigman, A. G Doyle, Science 2021, 374, 301-308; (b) S. Zhao, T. Gensch, B. Murray, Z. L. Niemeyer, M. S. Sigman, M. R. Biscoe, Science 2018, 362, 670-674.

[45] (a) J. M. Gil-Negrete, E. Hevia, Chem. Sci. 2021, 12, 1982 1992; (b) T. Elkoush, N. D. Reich, M. G. Campbell, Angew. Chem., Int. Ed. 2021, 60, 22614-22622; (c) W. Wang, C.-L. Ji, K. Liu, C.-G. Zhao, W. Li, J. Xie, Chem. Soc. Rev. 2021, 50, 1874-1912; (d) J.-W. Wang, D.-C. Zhong, T.-B. Lu, Coord. Chem. Rev. 2018, 377, 225-236; (e) R. J. Somerville, J. Campos, Eur. J. Inorg. Chem. 2021, 2021, 3488-3498.

[46] (a) M. C. Blanco, E. J. Fernández, P. G. Jones, A. Laguna J. M. López-de-Luzuriaga, M. E. Olmos, Angew. Chem., Int. Ed. 1998, 37, 3042-3043; (b) M. C. Blanco, E. J. Fernández, J. M. López-de-Luzuriaga, M. E. Olmos, O. Crespo, M. C. Gimeno, A. Laguna, P. G. Jones, Chem. Eur. J. 2000, 6, 4116-4123; (c) M. C. Blanco, E. J. Fernández, A. K. Fischer, P. G. Jones, A. Laguna, M. E. Olmos, M. D. Villacampa, Inorg. Chem. Commun. 2000, 3, 163-165; (d) M. Brym, C. Jones, J. D. E. T. Wilton-Ely, Inorg. Chem. 2005, 44, 32753282.

[47] P. Pyykkö, M. Atsumi, Chem. Eur. J. 2009, 15, 186-197.

[48] (a) H. Fang, S.-G. Wang, The Journal of Physical Chemistry A 2007, 111, 1562-1566; (b) P. Pyykkö, P. Zaleski-Ejgierd, J. Chem. Phys. 2008, 128, 124309; (c) J. Li, P. Pyykko, Inorg. Chem. 1993, 32, 2630-2634.

[49] E. Zeller, H. Beruda, A. Kolb, P. Bissinger, J. Riede, H. Schmidbaur, Nature 1991, 352, 141-143.

[50] (a) H. Schmidbaur, Gold Bull. 2000, 33, 3-10; (b) H Schmidbaur, Chem. Soc. Rev. 1995, 24, 391-400; (c) H. Schmidbaur, A. Schier, Chem. Soc. Rev. 2008, 37, 1931 1951.

[51] T. Iwai, T. Fujihara, Y. Tsuji, Chem. Commun. 2008, 62156217. 


\section{Entry for the Table of Contents}

- Mono-, di-, and tri-AuPhos

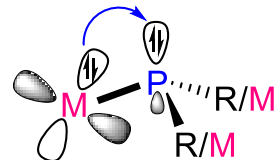

d-p $\pi$-repulsion
- Extremely electron-rich via d-p $\pi$-repulsion

- Sterically and electronically tunable

- Synthon for multi-nuclear TM complexes

- Catalysis

An intriguing class of free Au-substituted phosphines (AuPhos) featuring an electronically and sterically tunable, extremely electron-rich phosphorus center has been described. These AuPhos are potent synthons for multi-nuclear transition metal complexes and have tremendous potential for transition metal catalysis when electron-rich metal centers are required.

Institute and/or researcher Twitter usernames: @LLL_lab_SUSTech @SUSTechSZ 